\section{Neo-liberalism translated into preconditions for women entrepreneurs - two contrasting cases}

\author{
Malin Tillmar
}

School of Business and Economics, Linnaeus University Växjö, Vaxjo, Sweden

\author{
Helene Ahl \\ School of Education and Communication, Jönköping University, \\ Jönköping, Sweden \\ Karin Berglund \\ Stockholm Business School, Stockholm University, \\ Stockholm, Sweden, and \\ Katarina Pettersson \\ Department of Urban and Rural Development, \\ Swedish University of Agricultural Sciences, \\ Uppsala, Sweden
}

\begin{abstract}
Purpose - Contrasting two countries with different gender regimes and welfare states, Sweden and Tanzania, this paper aims to analyse how the institutional context affects the ways in which a neo-liberal reform agenda is translated into institutional changes and propose how such changes impact the preconditions for women's entrepreneurship.

Design/methodology/approach - This study uses document analysis and previous studies to describe and analyse the institutions and the institutional changes. This paper uses Scandinavian institutional theory as the interpretative framework.

Findings - This study proposes that: in well-developed welfare states with a high level of gender equality, consequences of neo-liberal agenda for the preconditions for women entrepreneurs are more likely to be negative than positive. In less developed states with a low level of gender equality, the gendered consequences of neo-liberal reforms may be mixed and the preconditions for women's entrepreneurship more positive than negative. How neo-liberalism impacts preconditions for women entrepreneurs depend on the institutional framework in terms of a trustworthy women-friendly state and level of gender equality.
\end{abstract}

(C) Malin Tillmar, Helene Ahl, Karin Berglund and Katarina Pettersson. Published by Emerald Publishing Limited. This article is published under the Creative Commons Attribution (CC BY 4.0) licence. Anyone may reproduce, distribute, translate and create derivative works of this article (for both commercial and non-commercial purposes), subject to full attribution to the original publication and authors. The full terms of this licence maybe seen at http://creativecommons.org/licences/by/4.0/ legalcode

Authors want to thank Professor William Gartner and Professor Leo-Paul Dana for their helpful comments. This research was funded primarily by the Swedish Research Council, Swedish Research Council for Health, Working Life and Welfare, as well as Vinnova.
Preconditions

Received 18 December 2020 Revised 6 March 2021 Accepted 13 March 2021 
JEC
16,4

604

Research limitations/implications - The study calls for bringing the effects on the gender of the neoliberal primacy of market solutions out of the black box. Studying how women entrepreneurs perceive these effects necessitates qualitative ethnographic data.

Originality/value - This paper demonstrates why any discussion of the impact of political or economic reforms on women's entrepreneurship must take a country's specific institutional context into account. Further, previous studies on neo-liberalism have rarely taken an interest in Africa.

Keywords Institutional change, Gender, Neo-liberalism, Sweden-Tanzania, Women's entrepreneruship

Paper type Research paper

\section{Introduction}

On a broad level, this article analyses how institutional contexts affect the translation and implementation of ideas that travel globally (Czarniawska and Joerges, 1996; Czarniawska and Sevon, 2005) such as neo-liberalism (Harvey, 2006). In line with scholars who have pointed to the role of the institutional context in entrepreneurship studies (Ahl, 2006; Klyver et al., 2013; Thebaud, 2011; Welter and Smallbone, 2011; Dana et al., 2020), we demonstrate why any discussion of the impact of political or economic reforms must take into account the specific institutional context of the country, including formal and informal institutions such as gender norms, questions of governance, state policies and the economy. As put by Palalic et al. (2020): "The neo-liberal argument that entrepreneurship is open and equal for everyone is shaky" (p. 3). By means of quantitative analysis and country comparisons, it has been argued that both formal and informal institutions are gendered and impact male and female entrepreneurs differently (Klyver et al., 2013; Thebaud, 2011). We add to this research by discussing how the translations of neo-liberal agendas impact and are impacted by national institutions, with specific attention to the gendered dimensions.

Inspired by anthropologists and entrepreneurship scholars (Marcus, 1986; Dana, 1997), we use contrasting as a methodological approach. The different institutional contexts studied, Sweden and Tanzania, serve as sources of inspiration and illustrations of theoretical points (Siggelkow, 2007), that are generated from an inductive interpretative research process (Dana and Dana, 2005). By contrasting a developed with a developing context and focussing our attention on the impact on women entrepreneurs, we also contribute to the current research dialogue on whether women's entrepreneurship as an instrument for economic growth is also an instrument for increased gender equality (Ramadani et al., 2013; Ramadani et al., 2015b; Anggadwita et al., 2016; Mazonde and Carmichael, 2016).

Neo-liberalism implies "new forms of political-economic governance premised on the extension of market relationships" (Larner, 2000), perpetuated by entrepreneurialism (Kantola and Squires, 2012). The institutional change resulting from neo-liberal agendas has been theorised as governmentality rather than direct government; a system of governance that makes people govern themselves according to the market logic (Lemke, 2001). Neoliberalism as a remedy for inefficient economies in the global south and north has in recent decades spread from the Western world (Duffield, 2010). The promotion of entrepreneurs and entrepreneurship is an inherent aspect of neo-liberalism. The significance of women's entrepreneurship is increasingly recognised, in a broad range of countries (Ramadani et al., 2015a). During the past few decades, women have been seen as an untapped resource in economic growth and development (Ramadani et al., 2013). At the same time, neo-liberalism has increasingly been criticised for its adverse effects (Harvey, 2006), including the restoration of undemocratic class society and for being inherently masculine (Garlick, 2020) 
with a negative impact on women and gender equality (Vasavi and Kingfisher, 2003). How then, are the preconditions for women entrepreneurs in the north and south affected by the neo-liberal wind blowing around the globe? And does it have the same effect for women everywhere?

While reforms in the neo-liberal era may have been similar, what has been reformed differs. To add nuance to this debate, we, therefore, contrast two countries with different points of departure in terms of gender regimes and welfare states; namely, Sweden, known for its gender equality and an encompassing welfare state and Tanzania, where the level of for women entrepreneurs

gender equality is low and the state is weak. Global studies on neo-liberalism rarely take an interest in Africa (Hilgers, 2012), which is another reason why contrasting a European country with one in Africa adds value.

Our research questions are: What institutional changes resulted from the translation of the neo-liberal agenda, affecting women entrepreneurs in the two countries? How have the reforms impacted the preconditions for women's entrepreneurship?

We take a normative, feminist perspective, which means that gender equality is the norm against which we discuss the results. Our view of gender equality encompasses both formal and substantive equality, that is to say, equality as equal opportunities such as equal access to business ownership and equality as equal results such as the same pay for the same job (Calás and Smircich, 2006). By gender, we mean not only physical men and women but also gendered social arrangements such as ideas of "men's work" or "women's work". We, therefore, pay attention not only to formal institutions but also to informal ones such as gender relations.

The article is structured as follows. In Section 2, we outline the frame of reference, which is based on (Scandinavian) institutionalism. In Section 3, we present our research methods. To answer the research questions, we use a three-step procedure. Firstly, Section 4 uses document studies to describe and analyse the institutional context including the gender dimension in both countries, historical and current. Secondly, Section 5 conducts a literature review to pinpoint the reforms which have affected the institutional contexts in the two countries. Thirdly, Section 6 discusses differences and similarities in these reforms and makes propositions about their impact on the preconditions for women entrepreneurs. Section 7 concludes the paper.

\section{Institutions and translation}

While some researchers have long argued the importance of cultural and political contexts (Dana, 1990, 1997; Johns, 2001), such insights are increasingly also gaining ground in entrepreneurship studies (Tillmar, 2006; Welter and Smallbone, 2011; Gaddefors and Anderson, 2017). Institutional theory is also increasingly being used as a lens (Hwang and Powell, 2005; Bruton et al., 2010; Welter and Smallbone, 2011; Yousafzai et al., 2015). For example, it has been argued that both formal and informal institutions are gendered and impacts male and female entrepreneurs differently (Klyver et al., 2013; Thebaud, 2011). In this paper, we use (Scandinavian) institutionalism to discuss how global neo-liberal ideas have been translated differently in different institutional contexts (Czarniawska and Sevon, 2005) and propose how this is likely to have affected preconditions for women's entrepreneurship differently.

\subsection{Institutional theory framework}

A common definition of an institution is "humanly devised constraints on repeated human interaction, that is, the rules of the game - both formal rules and informal norms" (North, 1988, p. 15). Institutions are both constraining and enabling, as they provide interpretative frames for thought and action (North, 1990). While North (1991) distinguished between 
formal and informal institutions [1], there are three dimensions of institutions in Scott's terminology (Scott, 1994; Scott, 2001). The regulative dimension consists of laws, rules and policies but also of control and evaluation systems and how these are created and maintained. This dimension maps on to North's formal institutions. The cognitive dimension consists of taken-for-granted views of "how things are" and the normative dimension consists of social norms and values. These can be seen as two dimensions of North's informal institutions.

The formal institutional framework has been comprehensively studied in the field of entrepreneurship, not least with regard to the framework conditions discussed by the Global Entrepreneurship Monitor (Steffens and Omarova, 2019). Formal institutions that are of particular significance for women's entrepreneurship are models of welfare provision, including social policy such as paid parental leave or the availability of public daycare (Ahl and Marlow, 2019; Ahl and Nelson, 2015; Berglund et al., 2018). Based on quantitative crosscultural comparisons, Thébaud (2016) and Klyver et al. (2013) conclude that when social policies that mitigate work-family conflict are in place - most commonly in developed countries - women opt for employment rather than entrepreneurship. That is, push-factors into entrepreneurship decrease. However, such policies enhance the economic and innovative capacity of the women who do enter into entrepreneurship (Thebaud, 2011). Other formal institutions of obvious significance for women's entrepreneurial opportunities are gender equality legislation, including inheritance laws and property rights for women.

Amongst informal institutions relevant to the present study, we consider the acceptance of corruption, which is related to trust in the state and trust in a free and fair market. When there is a low level of corruption and a high level of trust, business opportunities are more fairly available to all (Khadiagala, 2001; United Nations, 2005), including women (Khadiagala, 2001; Manji, 1999). We further consider the role of family and kin. A supportive family may facilitate women's business ownership (Kirkwood, 2009), but if the institution of gender relations is patriarchal, then family responsibilities may also be an obstacle (Tillmar, 2016a, 2016b). This may be the case when the formal institution gender equality legislation is weak and when social work/life policies are lacking; the informal institutions then interact with the formal ones. Such a situation does not favour the position of women. The framework presented here will be used to analyse the Swedish and Tanzanian institutions.

\subsection{Gender}

The term gender has come to refer to men and women but was originally devised to denote the institution of gender - the social construction of masculinity and femininity (West and Zimmerman, 1987; Butler, 2002) which, like any institution, has cognitive, normative and regulative dimensions: what a woman or a man "is", how a woman or a man "should behave" and possible regulations for the latter. Hence, in this article, we regard gender relations between men and women as an informal institution. The most prominent feature of the institution of gender is what Hirdman (1990) terms the gender order (or gender system), which is characterised by men and masculinity as the norm and by female subordination. It is not least visible in entrepreneurship, where the entrepreneur is typically assumed to be a man, unencumbered by the need to care for small children (Ahl, 2006).

At the same time, gender also affects other formal and informal institutions. If a conception, norm or regulation has different consequences for men and women it is said to be gendered. There is no clear-cut line between formal and informal institutions and gender is no exception. Informal institutions tend to uphold formal institutions and vice versa. For example, changes in informal gender relations such as those achieved by the suffrage movement may affect gender equality legislation (suffrage for women) which is a formal 
institution and the latter may further change informal gender relations (general acceptance of women's right to vote). This would be an example of institutional change.

In consequence of the above, models of welfare provision may be gendered, i.e. have different sorts of consequences for men and women. In the Scandinavian welfare state, welfare is provided by the state rather than by the family (as in the conservative welfare state) or through the market (as in the Anglo-Saxon, liberal welfare state) (Esping-Andersen, 1996). The result has been termed "the women-friendly state" (Hernes, 1988; Hernes, 1987). However, by calling for a reduced role of the state, neo-liberalism has challenged state feminism - women's Preconditions for women entrepreneurs movement activism in cooperation with women in government known as femocrats. Loosely coupled transnational networks have replaced national women's movements and the feminist engagement with public policy has decreased. It is argued that feminist action is increasingly dependent on the logic of the market, known as market feminism (Kantola and Squires, 2012), but it has been debated whether this is a step forward or if it represents a dark side of entrepreneurship (Wright and Zahra, 2011).

The entrepreneurship literature commonly sees women's entrepreneurship as an "untapped resource" for economic and social development, not least in transition economies (Ramadani et al., 2013) or in developing countries in Africa (Ratten and Jones, 2020). Women are here seen as a means to an end. However, it is also assumed that entrepreneurship will improve the situation of women in terms of increased financial independence (i.e. a market feminist approach). The literature recognises obstacles that women entrepreneurs must overcome, including social and cultural challenges (Anggadwita et al., 2016) family commitments (Ramadani et al., 2015a) or a variety of "patriarchal barriers" (Mazonde and Carmichael, 2016). How gendered structures impact women entrepreneurs in different economies is increasingly discussed (Ramadani et al., 2015b; Anggadwita et al., 2016). Empirical studies from Nordic contexts (Sundin and Holmquist, 1989; Alsos and Kolvereid, 2005; Kovalainen and Arenius, 2006; Neergaard and Thrane, 2011; Achtenhagen and Tillmar, 2013), transition economies (Palalić et al., 2020; Ramadani et al., 2015a; Ramadani et al., 2015b) or African countries (Mazonde and Carmichael, 2016; Tillmar, 2016a; Langevang et al., 2018), show that women entrepreneurs in different economies must deal with gendered institutions, but the nature and kind of these institutions, not least the market and the state, differ between the contexts, as do the implications for women.

It has been strongly argued that there is an affinity between masculinity, neo-liberalism (Garlick, 2020) and the nature of markets. Going back to Mises' work in the 1940s, Garlick (2020) suggests that "the regulation of effect is a crucial factor in the articulation of masculinity, economic markets and (neo)liberalism” (p. 555) and concludes that Mises' text is written entirely about and for men. A comparison between the US and India also showed many adverse effects of implementing policies that view women in poverty as economic agents (Vasavi and Kingfisher, 2003).

Yet markets need not be bad for women, claims feminist economist (McCloskey, 2000) if they are re-conceptualised as containing not only competition but also collaboration and followed by a feminist ideology. There are examples of feminist activism in the form of business, which has enabled institutional change (Berglund and Johansson, 2007; Tillmar, 2009b). The term FemInc.ism was coined to denote feminist activism through enterprise (Ahl et al., 2016). It can be used to analyse not only the potential for men and women to use the organisational form of enterprise and markets to enable institutional change but also to analyse potential pitfalls and constraints on this route. What neo-liberalism has meant for women entrepreneurs remains an empirical question.

In some contexts, women are simply pushed into entrepreneurship to avoid discrimination on the regular job market (Anggadwita et al., 2016; Heilman and Chen, 2003) 
or self-employment is the only way to make a living. However, the relationship between gendered institutions and women's entrepreneurship is complex. In a quantitative analysis, Klyver et al. (2013) show how the gender equality focus of a country can impact women's propensity to become self-employed - in an adverse way. This is especially the case in Scandinavia, where equality policies are geared towards the labour market rather than towards basic human rights and education for girls. Klyver et al. (2013) argue that women in Scandinavia prefer employment to business ownership because labour market rights such as parental leave, do not apply to the self-employed to the same extent as to employees.

To sum up, gender relations can themselves be seen as an informal institution, at the same time as they affect other institutions. Hence, all institutions can be gendered. In most countries, the regulative institutions are becoming gender-neutral in the sense that men and women have equal formal human rights. However, state policies affect men and women differently, making some states more "women-friendly" (Hernes, 1987) than others. The informal institutions of a society - i.e. the ongoing cognitive and normative constructions of what a man and a woman, respectively, is and should be and do - are often less gender-neutral (West and Zimmerman, 2009). In the following, we will discuss what this means for the institutional change studied.

\subsection{Institutional change translated}

According to neo-institutional theory, institutionalisation processes occur when organisations in an institutional field imitate each other because of isomorphic pressures either coercive, mimetic or normative - that lead to homogeneity and stability (Powell and DiMaggio, 1991). When the institutionalisation process is complete, the institution becomes taken for granted and unquestioned (Tolbert and Zucker, 1996). This theory has been criticised for being somewhat deterministic and for its inability to explain change; it is more concerned with how homogeneity and stability are achieved. Successful imitation would lead to complete isomorphism and everything would assume the same form. However, this is not always the case. Even in the globalised transnational context, there are not only trickle-down effects but also trickle-up effects (Salles-Djelic and Quack, 2018). Drawing on insights from Science and Technology Studies (Latour and Woolgar, 1979; Knorr-Cetina, 2013), Scandinavian institutionalism suggests the metaphor "translation" in place of imitation. Translation theory implies that institutions travel from one context to another in the form of objectified ideas and when the idea is taken up, the idea not only changes depending on how the local actors (re)interpret it but it also changes the local actors in the process (Czarniawska and Joerges, 1996; Czarniawska and Sevon, 2005; Wæraas and Nielsen, 2016). Translation theory as used in Scandinavian institutionalism, thus, emphasises variation and distinctiveness rather than homogeneity and stability. Different "idea carriers" (Sahlin-Andersson and Engwall, 2002) enable the circulation of practices and ideas, which are iteratively transformed in the process of becoming local arrangements (Wæraas and Nielsen, 2016). Rather than assuming isomorphic pressures, this translation perspective places attention on the different ways in which local actors "edit" the idea (Sevon, 1996; Wedlin and Sahlin, 2017).

Translation theory has been used to understand how global ideas such as educational practices (Hardy et al, 2012), CSR (Windell, 2006) and the use of standards (Boje, 2015) have swept around the world. Not least the "tidal wave" of neo-liberal reforms (Kjaer and Pedersen, 2001) and management discourses (Frenkel, 2005) have been analysed in these terms. We also find translation theory useful and in the coming sections, we identify how three distinctive neoliberal reforms - public-sector retrenchment, privatisation (formal institutions) and entrepreneurialism/individualism (an informal institution) - have been translated differently and how the translations have affected the contexts of the two countries. 


\section{Methods and data}

\subsection{Data}

We used document analysis and a literature review to describe and analyse the institutional situation and institutional change. Document analyses (Groenland and Dana, 2019) were used to describe the overall situation and the institutional setup in the two countries. The documents include official statistics and census data from both Tanzania and Sweden, as well as laws and official regulations (Appendix 1). With regard to the section on gender and institutions, previous studies and analysis of the relationship between formal institutions, feminism and the state in both contexts were also used.

To describe the institutional change that has taken place due to neo-liberal reforms, we have reviewed previous studies on neo-liberalism in each of the two contexts. We started with a broad search in the Scopus and Google Scholar databases using search words such as neo-liberal* and Tanzania/Sweden. The search results were narrowed down to published peer-reviewed papers. We started with the most cited papers and browsed through abstracts to select papers related to entrepreneurship and/or women for further study. Snowball sampling, where we read articles referred to in relevant papers, as well as recommendations from scholars specialised in neo-liberal reforms in the two countries, was also used. The 32 articles selected are referenced throughout the text in Section 5.

\subsection{Research process and analytical strategy}

The initial approach taken in this article is best characterised as inductive and interpretative, as called for by, for example, Dana and Dana (2005) if we are to gain a holistic understanding of the multifaceted and contextual phenomena of entrepreneurship.

The data consists of documents and previous studies on each of the two countries. We grew curious about the institutional change that had taken place in these, as we have done research on women's entrepreneurship in the two contexts over a long period of time. We, therefore, conducted a literature review to understand the changes we observed. Our efforts to understand the different reforms led us via theories on the institutional - and state - contexts to Scandinavian institutionalism and translation theory. Using institutional theory, we were able to categorise the formal and informal institutions in the two countries which affected the translations of the reforms, as shown in Table 1 . Thereafter, we revisited the 32 selected articles on the institutional change in the countries in the neo-liberal area and conducted a thematic analysis (Groenland and Dana, 2019). We categorised the institutional change according to which kinds of institutions (formal or informal) were affected. The result of this analysis is presented in Table 2. This latter part of our research process had an iterative "abductive" character (cf. Dana and Dumez, 2015; Alvesson and Skoldberg, 2000).

Contrasting one context with another (Brislin and Walter, 1973; Marcus, 1986) has been an important analytical strategy. We make no claims regarding the comparability of the two countries in the more positivist sense or on a "surface-level" (Alvesson and Skoldberg, 2000). The scientific results that can be expected from this research are geared towards highlighting mechanisms and redefining theories (cf. Dana and Dumez, 2015). In our case, we discuss mechanisms affecting the translation of reforms and we question taken for granted assumptions of positive outcomes of neo-liberalism. To avoid a comparison between the two nations in terms of ranking one higher than the other, which implicitly prioritises a Western notion (Ogbor, 2000), we use contrasting as an analytical strategy. Contrasting different cases is powerful not only for providing important theoretical conclusions but also for uncovering social phenomena and for understanding the reasons for different outcomes (Ragin, 2014). In studying institutional reforms and their impact on women's entrepreneurship, contrasting countries with very different levels of gender quality and 


\section{0}

Table 1.

Formal and informal institutions in

Sweden and

Tanzania

\begin{tabular}{llll}
\hline & & Sweden & Tanzania \\
\hline Formal institutions & $\begin{array}{l}\text { Property rights for women } \\
\text { Inheritance laws }\end{array}$ & $\begin{array}{l}\text { Strong } \\
\text { Strongly regulated and } \\
\text { gender equal }\end{array}$ & $\begin{array}{l}\text { Weak } \\
\text { Legal pluralism: customary } \\
\text { practices privilege men }\end{array}$ \\
& Model of welfare provision & Welfare provided by the & Welfare provided by family \\
& state & and kin \\
Informal institutions & Acceptance of corruption & Low & High \\
& Trust in the state & High & Low \\
& Trust in a free and fair market & High & Low \\
Role of family and kin & Weak & Strong \\
Gender relations & Comparatively equal & Comparatively unequal \\
\hline
\end{tabular}

\begin{tabular}{|c|c|c|c|}
\hline \multirow[b]{2}{*}{ Institutions } & \multicolumn{3}{|c|}{ Neo-liberal reforms affecting women's entrepreneurship } \\
\hline & Keywords & Tanzanian translation & Swedish translation \\
\hline \multirow[t]{2}{*}{ Formal institutions } & $\begin{array}{l}\text { Public-sector } \\
\text { retrenchment }\end{array}$ & $\begin{array}{l}\text { Cuts in social welfare (Caplan, } \\
\text { 2007; Pallotti, 2008) }\end{array}$ & $\begin{array}{l}\text { New public management } \\
\text { (Green-Pedersen, 2007; } \\
\text { Berg et al., 2008; Sundin } \\
\text { and Tillmar, 2010) } \\
\text { Cuts in social welfare } \\
\text { (Ginsburg and } \\
\text { Rosenthal, 2006) }\end{array}$ \\
\hline & Privatisation & $\begin{array}{l}\text { Privatisation of infrastructures } \\
\text { such as power, water, telecom, the } \\
\text { container terminal and Air } \\
\text { Tanzania (United Republic of } \\
\text { Tanzania, 2005) } \\
\text { Privatisation of land (Pallotti, } \\
\text { 2008) } \\
\text { Opening up for foreign } \\
\text { investments (Gibbon, 1995) }\end{array}$ & $\begin{array}{l}\text { Privatisation of } \\
\text { infrastructure such as } \\
\text { railway, } \\
\text { pharmaceuticals, } \\
\text { banking, forestry and } \\
\text { telecom (Gratzer } \text { et al., } \\
\text { 2010) } \\
\text { Outsourcing to private } \\
\text { businesses, customer- } \\
\text { choice systems, etc. } \\
\text { (Skolverket, 2014; } \\
\text { Sundin and Rapp, 2006; } \\
\text { Sundin and Tillmar, } \\
\text { 2010) }\end{array}$ \\
\hline Informal institutions & $\begin{array}{l}\text { Entrepreneurialism } \\
\text { and individualism }\end{array}$ & $\begin{array}{l}\text { Individual agency and promoted } \\
\text { locally (Pallotti, 2008) } \\
\text { Individualisation of land rights } \\
\text { (Pallotti, 2008) } \\
\text { Self-images shaped towards } \\
\text { independent and autonomous } \\
\text { citizenship (Sigalla and Carney, } \\
2012 \text { ) }\end{array}$ & $\begin{array}{l}\text { Entrepreneurship in } \\
\text { school-fostering the } \\
\text { enterprising self } \\
\text { (Berglund, 2013) } \\
\text { Making women } \\
\text { responsible for } \\
\text { developing an } \\
\text { entrepreneurial persona } \\
\text { (Kantola and Outshoorn, } \\
\text { 2007) }\end{array}$ \\
\hline
\end{tabular}

Table 2.

Features of neoliberal policies affecting women entrepreneurs in Sweden and Tanzania such as power, water, telecom, the infrastructure such as container terminal and Air railway,

pharmaceuticals, Privatisation of land (Pallotti, 2008) Opening up for foreign investments (Gibbon, 1995)

Individual agency and promoted

(Pallotti, 2008)

Self-images shaped towards dependent and autonomous citizenship (Sigalla and Carney, 2007) 
institutional set-up is consequently an advantage. A context is better understood when an alternative pattern is used to provide a contrast (Brislin and Walter, 1973; Stewart et al., 1994; Marcus, 1986).

In entrepreneurship studies, there is a need to expand the scope of methodologies used (Dana and Dana, 2005). Contrasting as an analytical approach is surprisingly rare, but a few notable examples have inspired and informed this study (Dana, 1990, 1997; Williams, 2007; Tillmar, 2006; Alkhaled and Berglund, 2018). We contrast two countries that diverge in many ways. In combination and when contrasted against each other, the two country cases

Preconditions for women entrepreneurs illustrate the gendering of institutions and the importance of the institutional framework for the outcomes of reforms, not the least in terms of gender. The two country cases have served as sources of inspiration and illustrations of theoretical points (Siggelkow, 2007).

\section{Contrasting institutions in Sweden and Tanzania}

In this section, we analyse Swedish and Tanzanian institutions, paying particular attention to those that have significance for women entrepreneurs and are subject to neo-liberal transformation and based on document and literature studies.

\subsection{Economy and country data}

As entrepreneurship in Africa as a whole is increasing in importance and the need for knowledge is being recognised \{Dana, 2018 \#2251\} it is essential to remember that this is a vast continent and includes many different contexts, each of which needs to be understood in its own right (cf. Ratten and Jones, 2020). The East African region and Tanzania, are a contrast to Scandinavia and Sweden, in many respects. The income per capita is considerably lower, the income distribution more uneven, life expectancy shorter, literacy levels lower and the economies are chiefly based on agriculture.

Tanzania is one of the three large countries within the East African Community (EAC), together with its neighbours Kenya and Uganda [2]. Tanzania, like the rest of the EAC, is one of the fastest-growing regions of the world in terms of gross domestic product (GDP). In the terms used by the Global Entrepreneurship Monitor (GEM) studies (Baldegger et al., 2020), the Tanzanian economy is, however, still "factor-driven", with agriculture using $88 \%$ of the employed population (FAO, 2014). Agriculture uses a higher percentage of women than men and women are over-represented amongst unpaid employees (FAO, 2014). A significant proportion of the workforce and particularly women (48\% compared to $34 \%$ amongst men) have multiple occupations (FAO, 2014). The state is struggling with foreign debt (www.worldbank.org), corruption (TransparencyInternational, 2016) and gender inequality (Global Gender Gap Report, 2015). Informal institutions enjoy a higher level of trust than formal (Havnevik and Hårsmar, 1999; Tillmar, 2006; Tillmar, 2016c). It has even been argued that the states of Sub-Saharan Africa are often empty shells masking the more important informal regulations which govern the countries (Chabal and Daloz, 1999). The Entrepreneurship Ecosystem is improving with regard to IT infrastructure and connectivity and shows some improvements in education, but there is little improvement in, for example, access to water, electricity or finance (Galperin and Melyoki, 2020).

The Scandinavian states are ranked amongst the least corrupt by Transparency International (www.transparency.org). Sweden is known for being a high-trust society, where formal institutions are aligned with the informal institutions and enjoy a high degree of citizens' trust (Trägårdh, 2013). The Swedish economy is "innovation-driven”, in GEM's terms and agriculture is not even amongst the 30 largest occupations. Yet the labour market is highly gender-segregated and only $16 \%$ of women work in gender-neutral occupations (Statistics Sweden, 2016). The most female-dominated professions are nursing and elderly 
care, where $93 \%$ of those employed are women. In the health and care sectors, $77 \%$ of the small business owners are female (Statistics Sweden, 2016). Appendix 1 provides an overview of the contrasts between the two countries, by means of official statistics.

\subsection{Gender}

In terms of formal institutions, the 1977 Tanzanian Constitution guarantees every person an equal right to own property and explicitly prohibits gender-based discrimination (Brown et al., 2003; Carpano, 2010; Constitution of the United Republic of Tanzania, 1977; Ezer, 2006). However, to understand the position of Tanzanian women, it is essential to recognise "Legal Pluralism" (Manji, 1999). State laws, although gradually improving, do not determine what happens in real life (Asiimwe, 2001). Customary land rights continue to exist alongside statutory laws [3]. While Tanzania has taken initiatives to increase the number of women in land-related decision-making bodies (Carpano, 2010; Duncan, 2014; Rwebangira, 1996), village assemblies are often dominated by men (Carpano, 2010; Rwebangira, 1996). In practice, the law is weak as far as women's inheritance rights and ownership of land are concerned (Carpano, 2010; Duncan, 2014). Gender relations are also unequal in terms of informal institutions. Abuse and violence are very common and have been experienced by two out of five women between the ages of 15 and 49 (ILO and UNWOMEN, 2018). In practice, women's rights in education and working life are also weak. Girls are expelled from school if pregnant and most women have precarious working conditions in agriculture or in the informal sector (Africa for Women's Rights Tanzania, 2018). There is no social welfare or job security in these situations. The public sector, where there is some job security, is male-dominated (Africa for Women's Rights Tanzania, 2018). Women who are formally employed have the right to a maximum of 84 days of maternity leave within a leave cycle of three years (Mywage.org, 2018) [4].

Indigenous women's movements in East Africa faced many challenges due to institutionalised patriarchy (Kinyanjui, 2012) and colonialisation [5]. Prior to colonialisation, women organised themselves (Berger et al., 2012) and even collectively imposed sanctions on husbands if women's rights were violated (Kamau, 2010; Kinyanjui, 2012). In the struggle for independence, women redirected their energies from their collective support amongst women towards the support of nationalist groups (Kinyanjui, 2012; Mikell, 1997) hoping, in vain, to be rewarded with autonomy.

Sweden and the other Scandinavian countries are known for their relative gender equality. (Esping-Andersen, 1996) placed the Scandinavian welfare state regimes in a special category with their tax-funded public services and care for children and the elderly, which have enabled high labour participation and financial independence for women. In Sweden, many laws and regulations for gender equality were implemented during the twenty century. This was enabled by the joint efforts of government representatives and the women's movements. The feminist women in government, the femocrats, were nourished and supported by the women's movement and vice versa [6]. Women researchers provided scholarly support. Sweden has, for example, a policy stating that all political decisions must be reviewed from a gender equality perspective (Bergqvist et al., 2007). The Swedish Gender Equality Agency oversees the policies. At the regional level, the county councils have gender equality experts and regional gender equality councils.

A comprehensive welfare system was built up during the 1960s and through the 1980s, which entailed a large expansion of the public sector in education, healthcare and social services and provided employment opportunities for many women. The result was a level of labour market participation for women which stood out internationally: $85 \%$ vis-à-vis $90 \%$ for men in 2019 (Statistics Sweden, 2020). However, at the same time, it has a highly gender- 
segregated labour market, in which men and women work in gender-segregated professions. Moreover, men predominantly work in the private sector and women in the public sector.

Many of the policies of the women-friendly state are designed to make it possible for women to take up paid employment. Joint taxation was replaced by individual taxation in 1971 (Selin, 2014) which encouraged women's labour market participation as the additional family income was not consumed by the strongly progressive tax system Sweden had at the time. Over the years, publicly subsidised daycare and pre-school, as well as 18 months of paid parental leave (for both parents combined) were introduced, making it possible for everyone to combine family and gainful employment.

Further, policies are in place to create equal working conditions for men and women. The Discrimination Act (SFS, 2016:828) forbids employers to discriminate against people on the grounds of, amongst other things, gender. The Act regulates harassment, sexual harassment, recruitment and working conditions.

In sum, the level of involvement by the state is a notable difference between the countries. In Tanzania, women have very little support from the state; rather than influencing policy for women, Tanzanian women's movements were co-opted by the state to further a post-colonial, nationalist agenda. In contrast, Swedish state feminism has resulted in legislation and reforms supportive of women. It has also resulted in entities within the state, women's policy agencies, tasked with working for and monitoring, the status of women (Kantola and Outshoorn, 2007). In Tanzania the women's movement became fragmented during the colonial era. If the institutions can be characterised as "friendly" in any way, they tend to be male-friendly. In Sweden, the women's movements have instead historically had the opportunity to work with and through the state institutions. Table 1 summarises the differences discussed above, in terms of the analytical categories of formal and informal institutions.

\section{The translations of neo-liberal agendas in Sweden and Tanzania}

In both Sweden and Tanzania, neo-liberal agendas have spread from the neo-liberal revolution in the Anglo-Saxon countries (Harvey, 2005) starting in the mid-1980s. However, as will be detailed below, our review of research on institutional reforms affecting women entrepreneurs in the two countries shows that neo-liberalism was "translated" (Czarniawska and Joerges, 1996) differently (see Appendices 2 and 3 for an overview in the form of timelines of reform programmes in the two countries).

We find that previous studies have shown that public-sector retrenchments, privatisation and entrepreneurialism, which imply individualism, have affected both countries (Table 2). In accordance with the frame of reference, we refer the first two to formal institutional change and the latter to changes in norms and assumptions, i.e. informal institutions. In the following, we describe how these changes have affected the two institutional contexts, respectively.

\subsection{The move towards neo-liberalism in Tanzanian politics}

Tanzania is characterised by being a "development state", which implies that the state is "materially and ideologically sustained through development relations" (Green, 2014, p. 15). In international development policy and practice, there was a shift from state-led to marketled development in the mid-1980s, known as the Washington Consensus (Gore, 2000). A core principle in this approach, implemented in the Structural Adjustment Programmes (SAP) of the International Monetary Fund (IMF) and the World Bank, is that governments should "liberalise domestic product and factor markets through privatisation and deregulation" (Gore, 2000, pp. 789-790).
Preconditions for women entrepreneurs 
JEC

16,4

614

Overall, the implementation of the Washington consensus through SAP in Tanzania (Gibbon, 1995; Havnevik, 1993) took place through the first wave of privatisation during the end of the 1980s and 1990s. Hence, SAP built on the neo-liberal arguments about the inefficiency of the state and the supremacy of private organising. The fundamental ideas were to incorporate the "Base of the Pyramid" into global capitalism (Prahalad, 2002) and by means of "Embedded Innovation" (Simanis, 2008) regard the poor as co-creators. These approaches were later heavily and increasingly criticised within the development debate (Gore, 2000; Büscher, 2010; Swyngedouw, 2005) for failing to acknowledge global explanations for underdevelopment (Gore, 2000) and for overlooking local dynamics (Arora and Romijn, 2012).

The implementation of SAP in Tanzania has been described as a shift from socialist selfreliance to neo-liberal partnerships (Engström, 2018). Tanzania was one of the first countries to comply, albeit reluctantly, with demands for public sector reforms (Green, 2014). The implementation of SAP took off when the socialist-orientated Julius Nyerere handed over the presidency to Ali Hassan Mwinyi in 1985. The term "privatisation of development" was used (Green, 2014) to describe the process. Changes included trade liberalisation deregulation in foreign direct investments and reforms in parastatal organisations and the civil service (Gibbon, 1995). The latter implied massive privatisation of land and infrastructure (energy, water, telecoms and transport), as well as cuts in government expenditure (Pallotti, 2008; Havnevik, 1993; Christen et al., 2005). As both the Tanzanian government and the foreign aid donors realised the negative social effects of the first version of SAP, social inclusion was incorporated during the 2000s through the National Strategy for Growth and Reduction for Poverty (NSGRP).

However, as phrased by Pallotti (2008, p. 222) "NSGRP maintains a strong neo-liberal focus on macroeconomic rigour and considers poverty reduction as the 'natural' result of economic growth". Special support to private sector development through different channels was part of this paradigm. Initiatives included SME incubators and microcredit schemes, as well as training of entrepreneurs and promotion of an "entrepreneurial attitude". Entrepreneurship support came high on the agenda. Taking Tanzania as a case in point, the Small Industries Development Organisation, Tanzanian Chamber of Commerce, Industry and Agriculture and Private Sector Development Fund are some of the organisations receiving both multilateral and bilateral development support. In the aftermath of the success of the Grameen Bank, many programmes included microcredits (Lindvert et al., 2015; Kinyanjui, 2012; Liljefors, 2011), which have been criticised for being a neo-liberal technology through which women are drawn into capitalism, whereby they move from being collaborators to facing each other as competitors (Karim, 2008) and thereby create ambivalence and conflict in relation to the collective communities on which they depend (Sigalla and Carney, 2012).

As shown in the previous section, Tanzania is heavily dominated by agriculture. In that sector, it was argued that the efficient production, processing and marketing of crops, as well as more investments and new technology, would increase yields and thereby alleviate poverty (Bluwstein et al., 2018; Stein, 2010). One important programme within the Tanzanian agricultural policy under President Kikwete (2005-2015) was Kilimo Kwanza (meaning agriculture first), whereby the private sector was heavily involved in large-scale investments in agriculture (Cooksey, 2012; Sikora et al., 2017). As part of this process, the Land Act was amended to give investors access to land which previously belonged to villages (Bluwstein et al., 2018). In 2008, during the financial crisis, public private partnerships was introduced as the "new development order" (Green, 2015, p. 636).

Donor support with regard to gender equality is directed to various initiatives for women's rights in Tanzania, but the projects supported are not necessarily in line with the agendas of the indigenous feminist movements. The women's groups, known as chamas - in 
Kiswahily, vyama - initially started as a way to address household needs, social needs and market coordination. The groups later evolved to address the experiences of women regarding discrimination and economic subordination (Kinyanjui, 2012). The chamas are examples of the important solidarity between women (cf. Sigalla and Carney, 2012) and are still very common and active. Critical voices argue that women's rights groups operating under the umbrella of donor-funded NGOs were conceived under neo-liberalism and, knowingly or otherwise, are participating in the imperial project (Shivji, 2007; Green, 2015). The relationship between the women's movements and the state, thus, remains complex and contradictory.

There are, nonetheless, indications that the neo-liberal wind may have abated during the latter part of the 2010s. The official discourse is that Tanzania has done well, which is also shown on a macro level by a large increase in GDP (Caplan, 2007). The expected trickledown effects of the growth are, however, debatable. For example, the local effects of the individualisation of agency and of land rights are being questioned. Pallotti (2008) argues that land reforms have not taken pre-existing local relationships and dynamics into account. Caplan (2007) showed through longitudinal ethnographic studies that many rural inhabitants have not benefitted from the urban growth. The effects differ between men and women, as gender equality has increased in some respects and more divorced or widowed women are choosing to remain unmarried (Caplan, 2007). Women entrepreneurs in Tanzania still struggle with and need to find strategies around, gender norms constraining their business activities (Langevang et al., 2018). Legal rights and justice when doing business have proven to be heavily gendered in Tanzania, leaving single women entrepreneurs exposed to many threats and weak institutional support (Tillmar, 2016c). Some women work around the gendered obstacles through, for example, locating their business in the home or partnering with a spouse (Langevang et al., 2018). At the same time, results from Zimbabwe show that entrepreneurship allowed women to improve their own and their families' lives (Mazonde and Carmichael, 2016) and similar bright examples have been reported from Tanzania (Tillmar, 2016d; Langevang et al., 2018).

Nonetheless, neo-liberal policies are still being implemented. Tanzania's Development Vision 2025 of becoming a middle-income country (URT, 2016) is influenced by the Big Results Now (BRN) transformation programme, which implies a "shift from working with government lens to adopting an investor's lens (p. 19) (BRN, 2013)." At the time of writing, however, the national debate in Tanzania is also seeing a "return of the state" not least regarding rights in the extractive sector (Jacob et al., 2016), in both the Mining Act of 2010 and the Petroleum Act (2015). However, the situation of smallholders remains precarious (Jacob et al., 2016). The current situation (2020) is uncertain, making future developments unpredictable.

\subsection{The move towards neo-liberalism in Swedish politics}

The first signs of neo-liberal policies in Sweden are often traced back to the end of the 1980s and the Social Democratic Minister of Finance Kjell-Olof Feldt (Bergqvist and Lindbom, 2003). Unlike their counterparts in neighbouring countries, the Swedish Social Democrats were positive to the adoption of New Public Management reforms (Green-Pedersen, 2007; Barry et al., 2008). However, the turning point in Swedish politics was the non-socialist coalition victory in the 1992 election in combination with the financial crisis. From having been a strong welfare state with high levels of services, heavy cuts were made (Ginsburg and Rosenthal, 2006). Neo-liberal policies included an increased emphasis on entrepreneurship, grounded in finding that most new jobs were created by small and new, firms (Birch, 1979). Markets were deregulated, publicly-owned companies were privatised 
and the publicly-organised welfare state was exposed to private sector competition. Stateowned businesses within banking, forestry and pharmaceuticals were sold during the 1990s and privatisation of the railways, telecommunications and public real estate followed a decade later (Gratzer et al., 2010).

With the privatisation of public sector service provision, a school voucher system, paving the way for publicly-funded privately-owned schools, was introduced in 1992 [7]. It was followed by a partial marketisation of other services which were still publicly funded. Cleaning and catering services for municipalities and hospitals were the first to be outsourced (Sundin and Rapp, 2006), followed by healthcare and care services. This phase of outsourcing was regulated by the Swedish Public Procurement Act (Swedish Public Procurement Act, 1992:1528) which allowed private firms to tender for contracts for these services. The second phase of marketisation followed in 2009, with the introduction of customer choice systems in care and healthcare, in line with the Act on Systems of Choice in the Public Sector (2008:962). This allows the customer to choose the service provider from amongst those authorised by the authority (municipality or county council). Since 2009, this system has been used in an increasing number of municipalities for services such as elderly care (Sundin and Tillmar, 2010). The result is a mix of public providers, private providers of different kinds and civil society organisations, all reimbursed according to the same logic.

In the public debate, the adverse effects of downsizing the public sector and the privatisation of healthcare and elderly care have become evident not least during the Covid19 pandemic [8]. However, empirical research had highlighted the gendered effects long before this. While policymakers and organisations such as the Swedish Agency for Economic and Regional Growth portray success stories, research shows numerous examples where women have become disempowered rather than empowered (Sundin and Rapp, 2006). In the wave of outsourcing, when the Swedish Public Procurement Act (1992:1526 and 2007:1091) came into effect, obstacles included units put out for tender being too large, the contract period too short and municipal trust in the businesses too weak (Tillmar, 2009a). After the first contract periods, women-owned businesses were often either bought up or out-competed by larger companies - owned and managed by men (Sundin and Tillmar, 2010). The percentage of businesses owned by women has indeed increased, but the majority of women are still found in small-scale services, retail and care; that is, in areas with low growth and earning potential. Hence, the traditional gender order was reproduced on the markets (Sundin, 2011; Sköld and Tillmar, 2015). Marketisation did not result in a bigger share of businesses being owned by women; in contrast, men's entrepreneurship increased in 12 of 15 industries (Sköld and Tillmar, 2015).

\section{Concluding discussion}

In this section, we return to our research questions, starting with how neo-liberal agendas have been translated into institutional reforms, impacting women entrepreneurs, in the two countries.

When contrasting our cases we see that formal institutions (North, 1991) or regulative pillars Scott, 2001 in both countries and during the same period of time were changed in line with neo-liberal agendas, but with different foci and implications. Privatisation is a common theme in formal institutional reform. Table 2, as well as Appendices 2 and 3, provides an overview of these institutional changes. Privatisation of state-owned enterprises and parastatals happened in both countries, as did public sector retrenchment, which we interpret as translations of neo-liberal agenda into institutional reforms. In both countries, neo-liberalisation has implied a shift of responsibility - from global and/or national 
institutions to the individual (Duffield, 2010) and from the elites to the ordinary citizen, who is expected to make her life more entrepreneurial (Lemke, 2001).

Other neo-liberal agendas were translated differently depending on the contexts (Czarniawska and Sevón, 1996). In Tanzania, an agrarian country with a small public and service sector and high levels of unemployment, the redirection of donor support from agriculture to entrepreneurship has had a strong impact. The institutional reforms centred on privatisation of land and natural resources. The welfare state of Sweden, on the other hand, concentrated on the privatisation of welfare and was greatly affected by new public management and initiatives to increase the number of private businesses providing welfare services. With regard to informal change, the reviewed studies (summarised in Table 2) showed that individualism and entrepreneurialism are promoted as norms (Scott, 2001) both in Tanzania (Pallotti, 2008; Sigalla and Carney, 2012) and in Sweden (Berglund, 2013; Kantola and Outshoorn, 2007). Nonetheless, the collective women's groups, chamas, retain their importance in Tanzania.

As neo-liberal agendas are known to favour entrepreneurship but not necessarily gender equality, we asked how the translations in the two countries impacted the preconditions for women's entrepreneurship. On this research question, we conclude our literature review by making three propositions.

In Sweden, the impact of neo-liberalism on the position of women is quite different from the story in Tanzania. The shift in Sweden has been from a situation where both formal and informal institutions (Table 1) were relatively conducive for women in general, and hence also for the women who were entrepreneurs. Swedish society was characterised by a high level of trust in both the state and the markets. Sweden had a Scandinavian welfare model, where feminism was institutionalised into state feminism. Within the neo-liberal ideology, as translated into the Swedish society, it has come to be taken for granted that deregulation of female-dominated operations in the public sector such as healthcare, education, childcare and elderly care increases the opportunities for women's entrepreneurship, and hence empowers women and improves equality. Previous studies have shown that the results for women entrepreneurs were not those expected. Hence, we propose the following:

P1. In well-developed welfare states with a high level of gender equality, consequences of neo-liberal agenda on the preconditions for women entrepreneurs are more likely to be negative than positive.

In Tanzania, the shift has been from a situation where both formal and informal institutions privileged men at the expense of women (Table 1). The country was struggling with dysfunctional state organisations. Welfare provision was seen as the responsibility of family and kin, which in this patriarchal society meant unpaid labour by women. African countries were not included in the typology of Esping-Andersen (1996), but, if anything, they resemble what he termed a conservative welfare regime. The neo-liberal agenda for Tanzania, as translated into donor policies, has led to a focus on entrepreneurialism with more mixed effects on women's entrepreneurship. Previous empirical studies on women-owned SMEs in Tanzania have only explored this issue to a limited extent. Adverse effects which leave impoverished and rural women worse off than men have been reported (Caplan, 2007). The same applies to adverse effects for impoverished single women (Tillmar, 2016c). However, there is also a bright side, where enterprise enables women to improve their own position and become independent of oppressive male structures (Tillmar, 2016d; Mazonde and Carmichael, 2016). Based on this study of the institutional situation and the translation of the reforms, we propose the following:
Preconditions for women entrepreneurs

617 
JEC

16,4

P2. In less developed states with a low level of gender equality, the gendered consequences of neo-liberal reforms may be mixed and the preconditions for women's entrepreneurship are more positive than negative.

Further empirical explorations are, however, needed to understand how the changes are experienced by women entrepreneurs.

The Swedish experiences provide strong support for state feminism. However, based on the studies from Tanzania, we propose that a prerequisite for such a scenario is a trustworthy state. That, in turn, first requires not only an independent state, which is well-integrated with norms and traditions but also a certain level of well-being in the community. Otherwise, the result is likely to be corruption and subsequent distrust. Provided that the wealth created remains within the country to a sufficient extent and also trickles down to smallholders and women entrepreneurs, well-being can result from economic growth:

P3. How neo-liberalism impacts preconditions for women entrepreneurs is highly dependent on the institutional framework in terms of a trustworthy women-friendly state and level of gender equality.

\section{Contributions and further studies}

\subsection{Contributions}

Within mainstream entrepreneurship studies, it is assumed that increased business ownership amongst women - and privatisation of female-dominated industries - improves not only economic development but also gender equality. Our literature review of two contrasting countries affected by neo-liberal reforms illustrates that such a development is not always the case. Previous studies have shown adverse effects on gender equality, not least in the Swedish welfare state. Our analysis demonstrates that reforms must be understood through their national institutional order, affecting first how reforms are translated and second what gendered consequences they have.

Furthermore, this study has contributed by problematising the neo-liberal agenda of privatisation and entrepreneurialism, hence showing not only the bright but also the dark sides of entrepreneurialism. By enriching our analysis with the gender perspective we show that translations of reforms and their effects have different gender consequences depending on the gendering of the pre-existing institutional framework. Theoretically, this implies that not only entrepreneurship studies but also (Scandinavian) institutional theory will benefit from taking a gender perspective into account when analysing effects on entrepreneurship. By focussing on women and contrasting a developed country in the global north with a developing country from the global south, we contribute to the ongoing development of broadening the base of entrepreneurship theorising from androcentric and northern/western ethnocentric perspectives.

\subsection{Further studies}

This paper has explored how the neo-liberal winds have affected institutional reforms in two contrasting contexts, with a focus on agendas that potentially impact women entrepreneurs. To discuss how women entrepreneurs themselves perceive these effects, there is a need to analyse qualitative ethnographic accounts of women entrepreneurs. In the extant literature, there is still greater knowledge about the perceptions of and effect on women entrepreneurs in the welfare state context, Sweden, than in the developing country, Tanzania. Hence, further empirical expirations are needed, particularly in the Tanzanian context. For example, further studies on the material dimension of the institutional situation have been 
called for (Jones et al., 2013). This includes delving deeper into the impact of contextual dimensions such as the solidarity amongst women within chamas, collectivist values (Kilby, 2020) and mutual cooperation (Anggadwita et al., 2016).

While the role of the institutional context - and translations - in entrepreneurial processes is increasingly acknowledged, the primacy of the free market is still taken for granted. This study indicates a need to bring the effects on gender of ideological agendas and functioning of markets out of the black box. From a gender perspective, examples of relevant further questions to ask about markets are: Is such a thing as a women-friendly

Preconditions for women entrepreneurs market emerging anywhere? In this neo-liberal era with many political changes and great turbulence, what happens to the relative women-friendliness of states? What happens to the women-friendliness of states when more facets of society are included in the rationality of the market?

Will the state in Sweden remain women-friendly and will the Tanzanian and, for example, other African states become more women-friendly?

While not unique, the contrasting analytical strategy used in this paper could be used to a greater extent in entrepreneurship studies. We hope to have inspired further use of it, to expand the scope of methodologies used to understand the contextdependence of entrepreneurial processes, as called for by Dana and Dana (2005). Theoretically, the potential of Scandinavian institutional theory for understanding and explaining entrepreneurial behaviour in various contexts affected by ideas that travel globally (Czarniawska and Sevon, 2005) is still a route to explore. If the winds should shift from neo-liberal agendas, what will be the next global ideas to affect (male and female) entrepreneurs in different countries differently? The call for sustainability in Agenda 2030 is one example of such global ideas that may be translated differently in different contexts and also affect entrepreneurs and gendering processes differently.

\section{Notes}

1. Examples of informal institutions are sanctions, taboos, customs, traditions and codes of conduct. Formal institutions would be, for example, constitutions, laws or property rights.

2. Rwanda and Burundi are the other two nations within the EAC.

3. The country currently has an ambitious, albeit incomplete, agenda for land and natural resources policy reforms, but the Constitution does not contain any direction in relation to customary laws (Duncan, 2014).

4. Parental leave for fathers, over and above three days after childbirth, is not on the agenda. The state does not provide childcare or elderly care assistance. This is provided in the homes by the women of the family and by kin and/or in exchange for food and housing by young female "house girls", often from the home villages.

5. Under colonialism, women's organisations were restructured with the aim of "civilizing" the women (Kinyanjui, 2012). This colonial approach and western ethnocentric view of African women has been criticised as the pre-colonial agency of African women has been highlighted (Healy-Clancy, 2012).

6. One example was the Support Stockings, who aimed for equal representation in parliament after the 1994 election. They orchestrated a perception that if this did not materialise they would form a feminist party. The other parties responded by making more women eligible for election, which resulted in the Swedish parliament becoming one of the most gender equal in the world (Bergqvist et al., 2007). Women in Sweden have, thus, used the state and the parliamentary system for the advancement of women, so-called "state feminism". 
7. Statistics from the Swedish National Agency for Education have shown that $20 \%$ of preschoolers, $14 \%$ of children in primary school and $26 \%$ of secondary school students were enrolled in privately owned schools in 2013 (Skolverket, 2014).

8. This critique includes lack of staff in elderly care, lack of reserve capacity in healthcare, coordination costs due to the diversity of ownership of both pharmacies and organisations providing health and care services.

\section{References}

Achtenhagen, L. and Tillmar, M. (2013), “Studies on women's entrepreneurship from Nordic countries and beyond", International Journal of Gender and Entrepreneurship, Vol. 5 No. 1.

Ahl, H. (2006), "Why research on women entrepreneurs needs new directions", Entrepreneurship Theory and Practice, Vol. 30 No. 5, pp. 595-621.

Ahl, H. and Marlow, S. (2019), "Exploring the false promise of entrepreneurship through a postfeminist critique of the enterprise policy discourse in Sweden and the UK", Human Relations, Vol. 74 No. 1, pp. 41-68.

Ahl, H. and Nelson, T. (2015), "How policy positions women entrepreneurs: a comparative analysis of state discourse in Sweden and the United States", Journal of Business Venturing, Vol. 30 No. 2, pp. 273-291.

Ahl, H., Berglund, K., Pettersson, K. and Tillmar, M. (2016), "From feminism to FemInc. ism: on the uneasy relationship between feminism, entrepreneurship and the Nordic welfare state", International Entrepreneurship and Management Journal, Vol. 12 No. 2, pp. 369-392.

Anggadwita, G., Saleh Luturlean, B., Ramadani, V. and Ratten, V. (2016), "Socio-cultural environments and emerging economy entrepreneurship: women entrepreneurs in Indonesia", Journal of Enterpreneurship in Emerging Economieis, Vol. 9 No. 1, pp. 85-96.

Alkhaled, S. and Berglund, K. (2018), “And now I'm free': women's empowerment and emancipation through entrepreneurship in Saudi Arabia and Sweden", Entrepreneurship and Regional Development, Vol. 30 Nos 7/8, pp. 877-900.

Alvesson, M. and Skoldberg, K. (2000), "Reflexive methodology: new vistas for qualitative".

Alsos, G.A. and Kolvereid, L. (2005), "Entrepreneurship among women in Norway", Women Entrepreneurs. Theory, Research and Policy Implications, pp. 44-58.

Arora, S. and Romijn, H. (2012), "The empty rhetoric of poverty reduction at the base of the pyramid", Organization, Vol. 19 No. 4, pp. 481-505.

Asiimwe, J. (2001), “Making women's land rights a reality in Uganda: advocacy for co-ownership by spouses", Yale Human Rights and Development Law Journal, Vol. 4, p. 171.

Baldegger, R., Gaudart, R. and Wild, P. (2020), “Global entrepreneurship monitor 2019/2020”, School of Management Fribourg.

Barry, J., Berg, E. and Chandler, J. (2008), "New public management and social work in Sweden and England: challenges and opportunities for staff in predominantly female", International Journal of Sociology and Social Policy, Vol. 28, pp. 114-128.

Berg, E.E., Barry, J.J. and Chandler, J.J. (2008), "New public management and social work in Sweden and England", International Journal of Sociology and Social Policy, Vol. 28 Nos 3/4.

Berger, I., Dublin, T. and Sklar, K.K. (2012), "Decolonizing women's activism: Africa in the transformation of international women's movements", Women and Social Movements, International.

Berglund, K. (2013), "Kärt barn har många namn: Om entreprenörskaps alla (o)möjliga former", in Mikael, H. and Hans, H. (Eds), Företagsekonomin Och Samhället, Studentlitteratur, Lund.

Berglund, K., Ahl, H., Pettersson, K. and Tillmar, M. (2018), "Women's entrepreneurship, neoliberalism and economic justice in the postfeminist era: a discourse analysis of policy change in Sweden", Gender, Work and Organization, Vol. 25 No. 5. 
Berglund, K. and Johansson, A.W. (2007), "Entrepreneurship, discourses and conscientization in processes of regional development", Entrepreneurship and Regional Development, Vol. 19 No. 6, pp. 499-525.

Bergqvist, C. and Lindbom, A. (2003), "The Swedish welfare state: neo-liberal challenge and welfare state resilience", Österreichische Zeitschrift für Politikwissenschaft, Vol. 32, pp. 389-401.

Bergqvist, C., Olsson Blandy, T. and Sainsbury, D. (2007), "Swedish state feminism: continuity and change", in Outshoorn, J. and Kantola, J. (Eds), Changing State Feminism, Palgrave Macmillan, Hampshire and New York, NY.

Preconditions for women entrepreneurs

Birch, D. (1979), The Job Generation Process, MIT Press, Cambridge, MA.

Bluwstein, J., Lund, J.F., Askew, K., Stein, H., Noe, C., Odgaard, R., Maganga, F. and Engström, L. (2018), "Between dependence and deprivation: the interlocking nature of land alienation in Tanzania", Journal of Agrarian Change, Vol. 18 No. 4, pp. 806-830.

Boje, D.M. (2015), Organizational Change and Global Standardization: Solutions to Standards and Norms Overwhelming Organizations, Routledge.

Brislin, R.W. and Walter, J. (1973), J. Lonner, and R.M. Thorndike. Cross-Cultural Research Methods, John Wiley and Sons, New York, NY.

BRN (2013), "Tanzania road map: national key result area agriculture. Government of Tanzania”, available at: www.pdb.go.tz/documents/Roadmaps/01.\%20Tanzania \%20BRN\%20Roadmap \%20

Brown, A., Laliberte, K. and Tubbs, E. (2003), Advocating for Social Change and Development: An Analysis of the Capacity of Local Women's Organizations in Tanzania, George Washington University, Washington, DC: Elliott School of International Affairs.

Bruton, G.D., Ahlstrom, D. and Li, H.L. (2010), "Institutional theory and entrepreneurship: where are we now and where do we need to move in the future?", Entrepreneurship Theory and Practice, Vol. 34 No. 3, pp. 421-440.

Butler, J. (2002), Gender Trouble: From Parody to Politics, Palgrave, London.

Büscher, B. (2010), "Anti-politics as political strategy: neoliberalism and transfrontier conservation in Southern Africa", Development and Change, Vol. 41 No. 1, pp. 29-51.

Calás, M.B. and Smircich, L. (2006), "From the 'woman's point of view' ten years later: towards a feminist organization studies", in Clegg, S. and Hardy, C. (Eds), The SAGE Handbook of Organization Studies, SAGE.

Caplan, P. (2007), "Between socialism and neo-liberalism: mafia island, Tanzania, 1965-2004”, Review of African Political Economy, Vol. 34 No. 114, pp. 679-694.

Carpano, F. (2010), “Strengthening women's access to land: the Tanzanian experience of the sustainable rangeland management project", Early version and part of a report prepared for the International Fund for Agricultural Development, available at: www.ifad.org/english/land/women_land/ WomenAndLand_Tanzania_Report_Eng.pdf

Chabal, P. and Daloz, J.P. (1999), “Africa works”, Disorder as political instrument.

Christen, R., Gökgur, N., Nellis, J. and Ruhl, O. (2005), "United republic of Tanzania: Privatization impact assessment: Infrastructure".

Constitution of the United Republic of Tanzania (1977), available at: www.judiciary.go.tz/downloads/ constitution.pdf

Cooksey, B. (2012), "Politics, patronage and projects: the political economy of agricultural policy in Tanzania”.

Czarniawska, B. and Joerges, B. (1996), "Travels of ideas", in Czarniawska, B. and Sevón, G. (Eds), Translating Organizational Change, Walter de Gruyter, Berlin, New York, NY.

Czarniawska, B. and Sevon, G. (Eds) (2005), Global Ideas: How Ideas, Objects and Practices Travel in the Global Economy, Liber and Copenhagen Business School Press, Fredriksberg, Denmark. 
Czarniawska, B. and Sevón, G. (Eds) (1996), Translating Organizational Change, Walter de Gruyter and Co, Berlin.

Dana, L.P. (1990), "Saint Martin/Sint Maarten: a case study of the effects of culture on economic development", Journal of Small Business Management, Vol. 28, p. 91.

Dana, L.P. (1997), "A contrast of Argentina and Uruguay: the effects of government policy on entrepreneurship”, Journal of Small Business Management, Vol. 35, p. 99.

Dana, L.P. and Dana, T.E. (2005), "Expanding the scope of methodologies used in entrepreneurship research", International Journal of Entrepreneurship and Small Business, Vol. 2 No. 1, pp. 79-88.

Dana, L.P. and Dumez, H. (2015), "Qualitative research revisited: epistemology of a comprehensive approach”, International Journal of Entreprenerushp and Small Busienss, Vol. 26 No. 2, pp. 154-170.

Dana, L.P., Ratten, V. and Honyenuga, B.Q. (2020), "Introduction to African entrepreneurship”, African Entrepreneurship: Challenges and Opportunities for Doing Business, Springer International Publishing AG.

Duffield, M. (2010), "The liberal way of development and the development - security impasse: Exploring the global life-chance divide”, Security Dialogue, Vol. 41 No. 1, pp. 53-76.

Duncan, J. (2014), "Women's land rights guide for Tanzania”, Landesa Center for Women's Land Rights.

Engström, L. (2018), Development delayed.

Esping-Andersen (1996), Welfare States in Transition: National Adaptations in Global Economies, Sage.

Ezer, T. (2006), "Inheritance law in Tanzania: the impoverishment of widows and daughters", Georgetown Journal of Gender and the Law, Vol. 7, p. 599.

FAO (2014), "Tanzania Mainland country profile: gender inequalities in rural employment in Tanzania Mainland: an overview Rome", Food and Agriculture Organization of the United Nations.

Frenkel, M. (2005), "The politics of translation: how state-level political relations affect the crossnational travel of management ideas", Organization, Vol. 12 No. 2, pp. 275-301.

Gaddefors, J. and Anderson, A. (2017), "Entrepreneursheep and context: when entrepreneurship is greater than entrepreneurs", International Journal of Entrepreneurial Behavior and Research, Vol. 23 No. 2, pp. 267-278.

Galperin, B.L. and Melyoki, L.L. (2020), “Tanzania as an emerging entrepreneurial ecosystem: prospects and challenges", African Entrepreneurship: Challenges and Opportunities for Doing Business, Springer International Publishing AG.

Garlick, S. (2020), "The nature of markets: on the affinity between masculinity and (neo) liberalism", Journal of Cultural Economy, pp. 1-13.

Gibbon, P. (1995), "Merchantisation of production and privatisation of development in post-Ujamaa Tanzania”, Liberalised Development in Tanzania, Nordiska Afrikainstitutet, Uppsala, pp. 9-36.

Ginsburg, H.L. and Rosenthal, M.G. (2006), "The ups and downs of the Swedish welfare state: general trends, benefits, and caregiving", New Politics, Vol. 11, p. 70.

Global Gender Gap Report (2015), in Forum, W.E. (ed.).

Gore, C. (2000), "The rise and fall of the Washington consensus as a paradigm for developing countries", World Development, Vol. 28 No. 5, pp. 789-804.

Gratzer, K., Lönnborg, M. and Olsson, M. (2010), "Staligt företagsägande och privatisering i sverige”, Nordiske Organisasjonsstudier, Vol. 12, pp. 94-112.

Green-Pedersen, C. (2007), "More than data questions and methodological issues: theoretical conceptualization and the dependent variable 'problem' in the study of welfare reform", Investigating Welfare State Change. The 'Dependent Variable Problem' in Comparative Analysis. Cheltenham/Northampton, Edward Elgar, pp. 13-23. 
Green, M. (2014), The Development State: aid, Culture and Civil Society in Tanzania, Boydell and Brewer.

Green, M. (2015), "After the MDGs: from social development to technoenterprise in Tanzania", Globalizations, Vol. 12 No. 4, pp. 629-644.

Groenland, E. and Dana, L.P. (2019), Qualitative Methodologies and Data Collection Methods: Toward Increased Rigour in Management Research, World Scientific.

Hardy, I., Edwards-Groves, C. and Rönnerman, K. (2012), "Collaborative learning as a travelling practice: how practices of learning 'travel", Educational Practice and Theory, Vol. 34 No. 2, pp. $5-22$.

Harvey, D. (2005), A Brief History of Neoliberalism, Oxford University Press, Oxford.

Harvey, D. (2006), "Neo-liberalism as creative destruction", Geografiska Annaler: Series B, Human Geography, Vol. 88 No. 2, pp. 145-158.

Havnevik, K.J. (1993), Tanzania: The Limits to Development from above, Nordic Africa Institute.

Havnevik, K.J. and Hårsmar, M. (1999), The Diversified Future. An Institutional Approach to Rural Development in Tanzania, Expert Group on Development Issues.

Healy-Clancy, M. (2012), "Women and the problem of family in early African nationalist history and historiography", South African Historical Journal, Vol. 64 No. 3, pp. 450-471.

Hernes, H. (1987), Welfare State and Women Power. Essays in State Feminism, Norwegian University Press, Oslo.

Hernes, H. (1988), "Scandinavian citizenship”, Acta Sociologica, Vol. 31 No. 3, pp. 199-215.

Hilgers, M. (2012), "The historicity of the neoliberal state”, Social Anthropology, Vol. 20 No. 1, pp. 80-94.

Hirdman, Y. (1990), The Gender System: theoretical Reflections on the Social Subordination of Women, Maktutredningen, Stockholm.

Hwang, H. and Powell, W.W. (2005), "Institutions and entrepreneurship", Handbook of Entrepreneurship Research, Springer.

ILO and UNWOMEN (2018), Business for Gender Equality, 4th Global Forum, [Online]. [Accessed].

Jacob, T., Pedersen, R.H., Maganga, F. and Kweka, O. (2016), "Rights to land and extractive resources in Tanzania (2/2): the return of the state", DIIS Working Paper.

Johns, G. (2001), "In praise of context”, Journal of Organizational Behavior, Vol. 22 No. 1, pp. 31-42.

Jones, C., Boxenbaum, E. and Anthony, C. (2013), "The immateriality of material practices in institutional logics", Institutional Logics in Action, Part A, Emerald Group Publishing.

Kamau, N. (2010), Women and Political Leadership in Kenya, Heinrich BollStiftung, Berlin. Retrieved January, 3, 2011.

Kantola, J. and Outshoorn, J. (2007), “Changing state feminism”, in Outshoorn, J. and Kantola, J. (Eds), Changing State Feminism, Palgrave Macmillan, Hampshire and New York, NY.

Kantola, J. and Squires, J. (2012), "From state feminism to market feminism?", International Political Science Review, Vol. 33 No. 4, pp. 382-400.

Karim, L. (2008), "Demystifying micro-credit: the Grameen bank, NGOs, and neoliberalism in Bangladesh”, Cultural Dynamics, Vol. 20 No. 1, pp. 5-29.

Khadiagala, L. (2001), "The failure of popular justice in Uganda: local councils and women's property rights", Development and Change, Vol. 32 No. 1, pp. 55-76.

Kilby, P. (2020), "Foreword by Peter Kilby", African Entrepreneurship: Challenges and Opportunities for Doing Business, Springer International Publishing AG.

Kinyanjui, M.N. (2012), Vyama: Institutions of Hope-Ordinary People's Market Coordination and Society Organization Alternatives, Nsemia, Oakville, Ontario, Canada.

Kirkwood, J. (2009), "Spousal roles on motivations for entrepreneurship: a qualitative study in New Zealand”, Journal of Family and Economic Issues, Vol. 30 No. 4, pp. 372-385.
Preconditions for women entrepreneurs 
Kjaer, P. and Pedersen, O. (2001), "Translating liberalization”, in Campbell, J. and Pedersen, O. (Eds), The Rise of Neoliberalism and Institutional Analysis, pp. 219-248.

Klyver, K., Nielsen, S.L. and Evald, M.R. (2013), “Women's self-employment: an act of institutional (dis) integration? A multilevel, cross-country study", Journal of Business Venturing, Vol. 28 No. 4, pp. 474-488.

Knorr-Cetina, K.D. (2013), The Manufacture of Knowledge: An Essay on the Constructivist and Contextual Nature of Science, Elsevier.

Kovalainen, A. and Arenius, P. (2006), Women's Entrepreneurship in Finland. Growth-Oriented Women Entrepreneurs and Their Businesses. A Global Perspective, Edward Elgar, Cheltenham, pp. 112-127.

Langevang, T., Hansen, M.W. and Kinunda Rutashobya, L. (2018), "Navigating institutional complexities. The response stragegies of Tanzanian female entrepreneurs", International Journal of Gender and Entrepreneurship, Vol. 3 No. 10, pp. 224-242.

Larner, W. (2000), "Neo-liberalism, policy, ideology, governmentality", Studies in Political Economy, Vol. 63 No. 1, pp. 5-25.

Latour, B. and Woolgar, S. (1979), Laboratory Life: The Social Construction of Scientific Facts, Sage Publications, Beverly Hills.

Lemke, T. (2001), "The birth of bio-politics: Michel Foucault's lecture at the collège de France on neoliberal governmentality", Economy and Society, Vol. 30 No. 2, pp. 190-207.

Liljefors, E. (2011), "Small-scale credit and social relations: a study of micro-finance users belonging to three providers of microfinance services in Kenya, 2002-2006", Ekonomisk-Historiska mötet 2011.

Lindvert, M., Yazdanfar, D. and Boter, H. (2015), "Perceptions of financial sources among women entrepreneurs in Tanzania", African Journal of Economic and Management Studies, Vol. 6 No. 2 , p. 197.

Mccloskey, D. (2000), "Post-modern free-market feminism: a conversation with Gayatri Chakravorty Spivak", Rethinking Marxism, Vol. 12 No. 4, pp. 27-37.

Manji, A.S. (1999), "Imagining women's'legal world': towards a feminist theory of legal pluralism in Africa”, Social and Legal Studies, Vol. 8 No. 4, pp. 435-455.

Marcus, G.E. (1986), Anthropology as Cultural Critique: An Experimental Moment in the Human Sciences, University of Chicago Press, Chicago.

Mazonde, N.B. and Carmichael, B. (2016), "The influence of culture on female entrepreneurs in Zimbabwe", The Southern African Journal of Entrepreneurship and Small Business Management, Vol. 8 No. 1, p. a101.

Mikell, G. (1997), African Feminism: The Politics of Survival in Sub-Saharan Africa, University of PA Press, Philadephia.

Mywage.org (2018), Tanzania.

Neergaard, H. and Thrane, C. (2011), "The Nordic welfare model: barrier or facilitator of women's entrepreneurship in Denmark?", International Journal of Gender and Entrepreneurship, Vol. 3 No. 2.

North, D.C. (1988), "Ideology and political/economic institutions", Cato Journal, Vol. 8, p. 15.

North, D.C. (1990), Institutions, Institutional Change and Economic Performance, Cambridge University Press.

North, D.C. (1991), Journal of Economic Perspectives, Vol. 5 No. 1, pp. 97-112.

Ogbor, J.O. (2000), "Mythicizing and reification in entrepreneurial discourse: ideology-critique of entrepreneurial studies", Journal of Management Studies, Vol. 37 No. 5, pp. 605-635.

Pallotti, A. (2008), “Tanzania: decentralising power or spreading poverty?", Review of African Political Economy, Vol. 35 No. 116, pp. 221-235. 
Powell, W. and Dimaggio, P. (1991), The New Institutionalism in Organizational Analysis, 1st ed., The University of Chicago Press, Chicago.

Prahalad, C.K. (2002), “The fortune at the bottom of the pyramid”, Strategy + Business, Vol. 26.

Ragin, C.C. (2014), The Comparative Method: Moving beyond Qualitative and Quantitative Strategies, University of CA Press.

Ramadani, V., Gërguri, S. and Dana, L.P. (2013), "Women entreprenerus in the Republic of Macedonia: waiting for directions", International Journal of Entrepreneurship and Small Business, Vol. 19 No. 1, pp. 95-121.

Ramadani, V., Rexhepi, G., Abaxi-Alili, H., Beqiri, B. and Thaci, A. (2015a), "A look at female entrepreneurship in Kosovo: an exploratory study", Journal of Enterprising Communities: People and Places in the Global Economy, Vol. 9 No. 3, pp. 277-294.

Ramadani, V., Hisrich, R.D. and Gërguri-Rashiti, S. (2015b), "Female entrepreneurs in transition economies: insights from Albania, Macedonia and Kosovo", World Review of Entrepreneurship, Management and Sustainable Development, Vol. 11 No. 4, pp. 391-413.

Ratten, V. and Jones, P. (2020), "Bringing Africa into entrepreneurship research", in African Entrepreneurship: Challenges and Opportunities for Doing Business, Springer International Publishing AG.

Palalić, R., Knezović, E. and Dana, L.P. (2020), Women's Entrepreneurship in the Former Yugoslavia: Historical Framework, Ecosystem, and Future Perspectives for the Region, Springer.

Rwebangira, M.K. (1996), The Legal Status of Women and Poverty in Tanzania, Nordic Africa Institute.

Sahlin-Andersson, K. and Engwall, L. (2002), The Expansion of Management Knowledge: Carriers, Flows, and Sources, Stanford University Press.

Salles-Djelic, M.L. and Quack, S. (2018), "Institutions and transnationalization", in Greenwood, R., Oliver, C., Sahlin-Andersson, K. and Suddab, R. (Eds) The Sage Handbook of Organizational Institutionalism, SAGE Publications.

Scott, W.R. (1994), "Institutions and organizations. Towards a theoretical synthesis", in Scott, W.R. and Meyer, J.W. (Eds), Institutional Environments and Organizations, Sage, Thousand Oaks, CA.

Scott, W.R. (2001), Institutions and Organizations, SAGE, Thousand Oaks, CA.

Selin, H. (2014), "The rise in female employment and the role of tax incentives. An empirical analysis of the Swedish individual tax reform of 1971", International Tax and Public Finance, Vol. 21 No. 5, pp. 894-922.

Sevon, G. (1996), "Organizational imitation in identity transformation”, in Czarniawska, B. and Sevon, G. (Eds), Translating Organizational Change, Walter de Gruyter, Berlin.

SFS (1992), SFS 1992. Lag (1992:1528) om offentlig upphandling. In: RS, F. (ed.) SFS 1992:1528, Regeringskansliet, Stockholm.

SFS (2007), 2007:1091. Lag (2007:1091) om offentlig upphandling. In: RS, F. (ed.) SFS 2007:1091, Regeringskansliet, Stockholm.

SFS (2016), SFS 2016:828. Diskrimineringslag. In: AFFAIRS]., S. M. O. H. A. S. (ed.).

Shivji, I.G. (2007), Silences in NGO Discourse: The Role and Future of NGOs in Africa, Fahamu/ Pambazuka.

Sigalla, R.J. and Carney, S. (2012), "Poverty reduction through entrepreneurship: microcredit, learning and ambivalence amongst women in urban Tanzania", International Journal of Educational Development, Vol. 32 No. 4, pp. 546-554.

Siggelkow, N. (2007), "Persuasion with case studies", Academy of Management Journal, Vol. 50 No. 1, pp. 20-24.

Sikora, R., Terry, E.R., Vlek, P. and Chitja, J. (2017), Transforming Agriculture in Southern Africa: Constraints, Technologies, Policies and Processes, Taylor and Francis.
Preconditions for women entrepreneurs 
Simanis, E. (2008), The Base of the Pyramid Protocol: Toward Next Generation BoP Strategy, Second Edition, available at: www.bop-protocol.org/docs/

Skolverket (2014), Privata aktörer inom förskola och skola, Skolverket, Stockholm.

Sköld, B. and Tillmar, M. (2015), "Resilient gender order in entrepreneurship: the case of Swedish welfare industries", International Journal of Gender and Entrepreneurship, Vol. 7 No. 1, pp. 2-26.

SOU (1992), Fristående skolor: Bidrag och elevavgifter, in Utbildningsdepartementet, A.F. (Ed.) 1992:38, Stockholm.

SOU (2008), LOV att välja - Lag Om Valfrihetssystem, in Socialdepartementet (ed.) 2008:15, Regeringskansliet, Stockholm.

Statistics Sweden (2016), Women and Men in Sweden. Facts and Figures 2016, Statistics Sweden, Örebro.

Statistics Sweden (2020), "Women and men in Sweden. Facts and figures 2020", X10.

Steffens, P.R. and Omarova, A. (2019), "Global Entrepreneurship Monitor (GEM)-2017/18 Australian National Report".

Stein, H. (2010), "World bank agricultural policies, poverty and income inequality in Sub-Saharan Africa", Cambridge Journal of Regions, Economy and Society, Vol. 4 No. 1, pp. 79-90.

Stewart, R., Barsoux, J.L., Kieser, A., Ganter, H.D. and Walgenbach, P. (1994), Managing in Britain and Germany, Springer.

Sundin, E. (2011), "Entrepreneurship and the reorganization of the public sector: a gendered story", Economic and Industrial Democracy, Vol. 32 No. 4, pp. 631-653.

Sundin, E. and Holmquist, C. (1989), Kvinnor som företagare: osynlighet, mångfald, anpassning: en studie, Liber.

Sundin, E. and Rapp, G. (2006), "Städerskorna som försvann, Individen i den offentliga sektorn [the cleaners who dissappeared: the individual in the public sector]", Arbetsliv $i$ omvandling, Arbetslivsinstitutet, Stockholm.

Sundin, E. and Tillmar, M. (2010), "Masculinisation of the public sector: local-level studies of public sector outsourcing in elder care", International Journal of Gender and Entrepreneurship, Vol. 2 No. 1, pp. 49-67.

Swedish Public Procurement Act (1992), Swedish Public Procurement Act 1992:1528, Konkurrensverket, Stockholm. [Swedish Competition Authority].

Swyngedouw, E. (2005), "Governance innovation and the citizen: the Janus face of governance-beyondthe-state”, Urban Studies, Vol. 42 No. 11, pp. 1991-2006.

Thebaud, S. (2011), "Social policies and entrepreneurship: Institutional foundations of gender gaps across 24 countries", Academy of Management Proceedings, 2011, Academy of Management Briarcliff Manor, New York, NY 10510, pp. 1-6.

Thébaud, S. (2016), "Passing up the job: the role of gendered organizations and families in the entrepreneurial career process", Entrepreneurship Theory and Practice, Vol. 40 No. 2, pp. 269-287.

Tillmar, M. (2006), "Swedish tribalism and Tanzanian entrepreneurship: preconditions for trust formation”, Entrepreneurship and Regional Development, Vol. 18 No. 2, pp. 91-107.

Tillmar, M. (2009a), "No longer so strange? (Dis)trust in municipality-small business relationships", Economic and Industrial Democracy, Vol. 30 No. 3, pp. 1-28.

Tillmar, M. (2009b), "Societal entrepreneurs in the health sector: crossing the frontiers", Social Enterprise Journal, Vol. 5 No. 3, pp. 282-298.

Tillmar, M. (2016a), "The gendered contextualization of SME cooperation in urban East Africa", pp. 105-123. 
Tillmar, M. (2016b), "The gendered contextualization of SME cooperation in urban East Africa", Women's Entrepreneurship in Global and Local Contexts, Edward Elgar Publishing.

Tillmar, M. (2016c), "Gendering of commercial justice - experience of self-employed women in urban Tanzania", Journal of Enterprising Communities: People and Places in the Global Economy, Vol. 10 No. 1, pp. 101-122.

Tillmar, M. (2016d), "Self-employed women's everyday innovations in East Africa", Research Handbook on Gender and Innovation.

Tolbert, P.S. and Zucker, L.G. (1996), "The institutionalization of institutional theory", in Clegg, S., Hardy, C. and Nord, W.R. (Eds), Handbook of Organization Studies, Sage, London.

TransparencyInternational (2016), "The global civil society organisation leading the fight against corruption".

Trägårdh, L. (2013), "The historical incubators of trust in Sweden: from the rule of blood to the rule of law", Trust and Organizations, Springer.

United Nations (2005), "United nations convention against corruption. In: UNITED NATIONS, O. O. D. A. C. (Ed). article 68(1)", available at: www.unodc.org/unodc/en/corruption/uncac.html

URT (2016), "Draft the national land policy. In: TANZANIA, U. R. O. (ed.)", Dar es Salaam, Tanzania.

Wæraas, A. and Nielsen, J.A. (2016), "Translation theory 'translated': three perspectives on translation in organizational research", International Journal of Management Reviews, Vol. 18 No. 3, pp. 236-270.

Vasavi, A. and Kingfisher, C.P. (2003), "Poor women as economic agents: the neo-liberal state and gender in India and the US", Indian Journal of Gender Studies, Vol. 10 No. 1, pp. 1-24.

Wedlin, L. and Sahlin, K. (2017), "The imitation and translation of management ideas", The SAGE Handbook of Organizational Institutionalism, pp. 102-127.

Welter, F. and Smallbone, D. (2011), "Institutional perspectives on entrepreneurial behavior in challenging environments", Journal of Small Business Management, Vol. 49 No. 1, pp. 107-125.

West, C. and Zimmerman, D.H. (1987), “Doing gender”, Gender and Society, Vol. 1 No. 2, pp. 125-151.

West, C. and Zimmerman, D.H. (2009), "Accounting for doing gender", Gender and Society, Vol. 23 No. 1, pp. 112-122.

Williams, C.C. (2007), "Socio-spatial variations in the nature of entrepreneurship", Journal of Enterprising Communities: People and Places in the Global Economy, Vol. 1 No. 1, pp. 27-37.

Windell, K. (2006), Corporate Social Responsibility under Construction: Ideas, Translations, and Institutional Change, Företagsekonomiska Institutionen.

Wright, M. and Zahra, S. (2011), "The other side of paradise: eexamining the dark side of entrepreneurship", Entrepreneurship Research Journal, Vol. 1 No. 3.

Yousafzai, S.Y., Saeed, S. and Muffatto, M. (2015), "Institutional theory and contextual embeddedness of women's entrepreneurial leadership: evidence from 92 countries", Journal of Small Business Management, Vol. 53 No. 3, pp. 587-604.
Preconditions for women entrepreneurs 


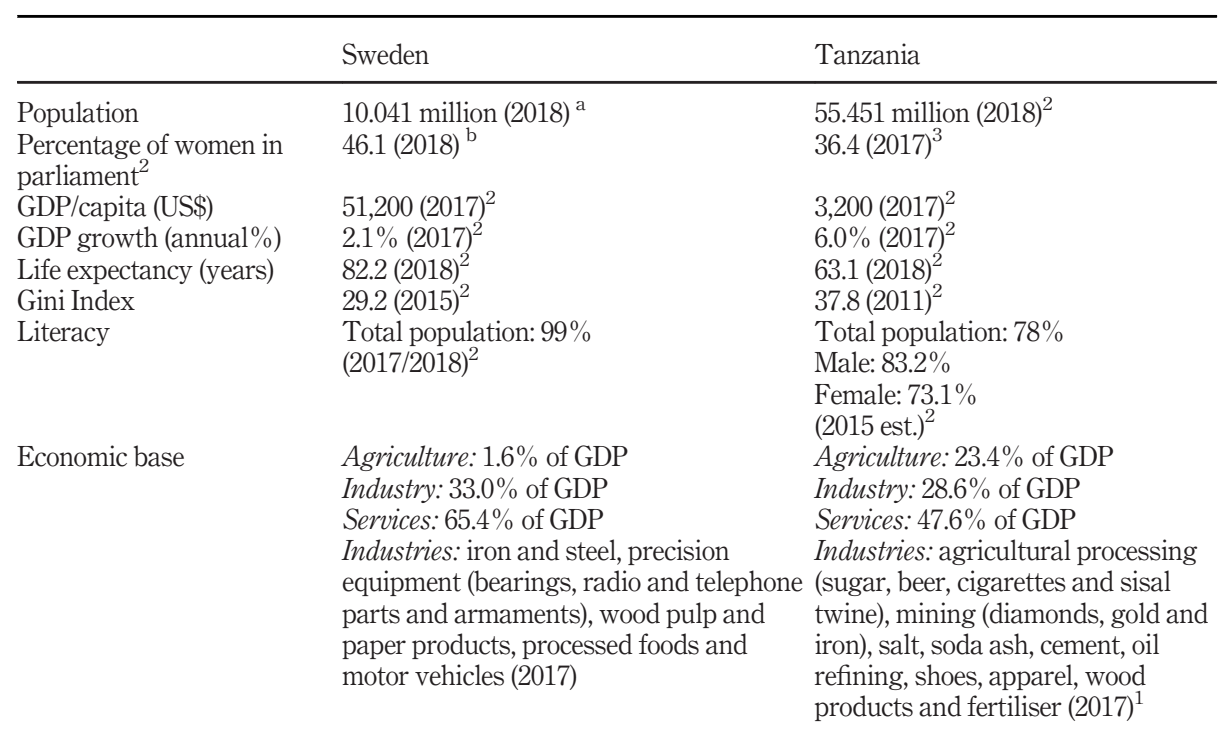

Table A1.

An overview of the contrasting countries understudy
Notes: ${ }^{a}$ www.cia.gov/library/publications/the-world-factbook/fields/2103.html\#136 [Accessed 19 November 2018] http://data.worldbank.org/ [Accessed 19 November 2018]. ${ }^{\mathrm{b}}$ www.indexmundi.com/map/?v=39 [Accessed 19 November 2018]. Percentage of woman in parliament: Proportion of seats held by women in national parliament $(\%)$. Literacy: Adult literacy rate, population $15+$ years can read and write, both sexes $(\%)$ 


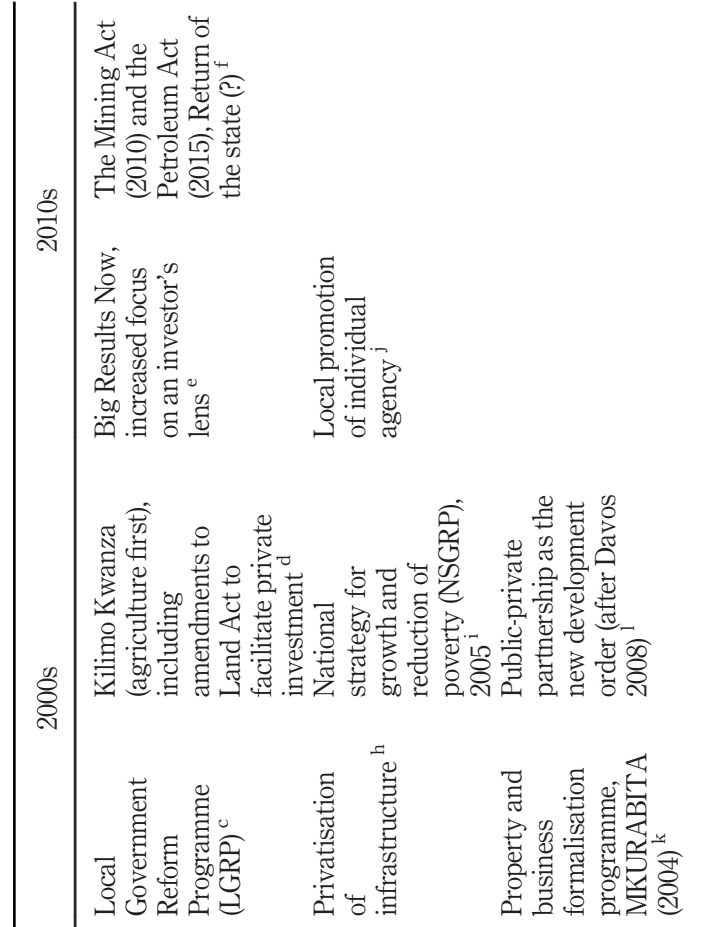

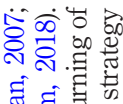

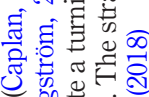
노 뻥

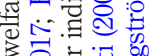

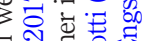

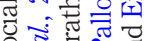

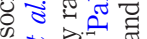
$\exists$ 递度递

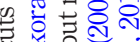
के चै जิ

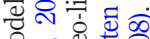

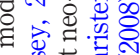

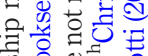

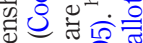

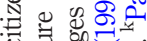
言空 늘

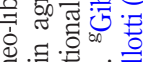

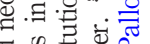

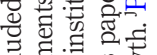

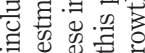
马. द्ध 정응 웅 要

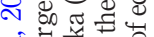
है 층

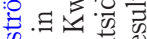
도능 중 늘 $\alpha$. $8.5 \underbrace{\pi}$ 词 E气

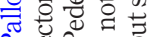
సٓ

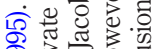

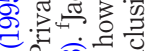
क्षे

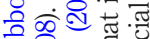

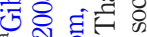

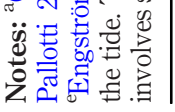

Table A2. Examples of reforms and policies affecting women entrepreneurs in Tanzania 


\begin{tabular}{|c|c|c|c|c|c|}
\hline \multirow[b]{2}{*}{$\begin{array}{l}\text { Before } 1990 \\
\text { Deregulation } \\
\text { of capital } \\
\text { controls, } \\
\text { changes in the } \\
\text { tax system to } \\
\text { increase work- } \\
\text { incentives and } \\
\text { autonomy } \\
\text { granted to } \\
\text { central bank a }\end{array}$} & \multicolumn{2}{|c|}{$1990 \mathrm{~s}$} & \multicolumn{2}{|l|}{$2000 \mathrm{~s}$} & \multirow{2}{*}{$\begin{array}{l}\quad \text { 2010s } \\
\text { Implementation } \\
\text { of customer- } \\
\text { choice in } \\
\text { increasing } \\
\text { numbers of } \\
\text { municipalities }\end{array}$} \\
\hline & $\begin{array}{l}\text { School } \\
\text { voucher } \\
\text { system } \\
\text { introduced in } \\
1992^{b}\end{array}$ & $\begin{array}{l}\text { State-owned } \\
\text { businesses in } \\
\text { banking, } \\
\text { forestry and } \\
\text { pharmaceuticals }_{\text {sold }^{c}}\end{array}$ & $\begin{array}{l}\text { State-owned } \\
\text { businesses in } \\
\text { railways, } \\
\text { telecommunications } \\
\text { and public real } \\
\text { estate sold }^{\text {d }}\end{array}$ & $\begin{array}{l}\text { Introduction } \\
\text { of } \\
\text { the } \\
\text { customer- } \\
\text { choice } \\
\text { system in } \\
\text { the public } \\
\text { sector } \\
\text { (including } \\
\text { e.g. elderly } \\
\text { care) }\end{array}$ & \\
\hline & $\begin{array}{l}\text { Outsourcing } \\
\text { and partial } \\
\text { marketisation } \\
\text { of publicly } \\
\text { funded } \\
\text { services, } \\
\text { starting with } \\
\text { cleaning and } \\
\text { catering }\end{array}$ & & $\begin{array}{l}\text { Cuts in social } \\
\text { welfare }^{f}\end{array}$ & & $\begin{array}{l}\text { Focus on } \\
\text { entrepreneurship } \\
\text { in schools }{ }^{g}\end{array}$ \\
\hline
\end{tabular}

Table A3.

Examples of reforms and policies affecting women entrepreneurs in Sweden

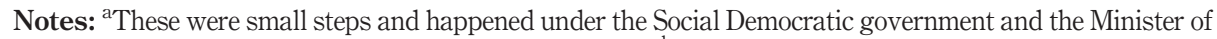
Finance, Kjell-Olof Feldt. (Bergqvist and Lindbom, 2003). ${ }^{\mathrm{b}} \mathrm{SOU}$ (1992:38). ${ }^{\mathrm{C}}$ Gratzer et al. (2010), Sundin and Rapp, (2006), Swedish Public Procurement Act SFS (1992:1528). ${ }^{\mathrm{d}}$ Gratzer et al. (2010). ${ }^{\mathrm{e}}$ Sundin and Tillmar (2010). ${ }^{\mathrm{f}}$ Ginsburg and Rosenthal (2006), SOU (2008). ${ }^{\mathrm{B}}$ Berglund (2013)

\section{Corresponding author}

Malin Tillmar can be contacted at: malin.tillmar@lnu.se

For instructions on how to order reprints of this article, please visit our website: 